\title{
Meta
}

Journal des traducteurs

Translators' Journal

\section{Colin, Joan and Ruth Morris (1996) : Interpreters and the Legal Process, Winchester, Waterside Press}

\section{Miriam Shlesinger}

Volume 43, numéro 1, mars 1998

La traduction et l'interprétation en Israël

Translation and Interpreting in Israel

URI : https://id.erudit.org/iderudit/004137ar

DOI : https://doi.org/10.7202/004137ar

Aller au sommaire du numéro

Éditeur(s)

Les Presses de l'Université de Montréal

ISSN

0026-0452 (imprimé)

1492-1421 (numérique)

Découvrir la revue

Citer ce compte rendu

Shlesinger, M. (1998). Compte rendu de [Colin, Joan and Ruth Morris (1996) : Interpreters and the Legal Process, Winchester, Waterside Press]. Meta, 43(1), 157-158. https://doi.org/10.7202/004137ar d'utilisation que vous pouvez consulter en ligne.

https://apropos.erudit.org/fr/usagers/politique-dutilisation/ 


\section{COMPTES RENDUS}

COLIN, Joan and Ruth MORRIS (1996): Interpreters and the Legal Process, Winchester, Waterside Press.

It is only in the past decade or so that non-conference interpreting has begun to receive the academic and professional attention it deserves. Along with the growing interest in dialogue interpreting (e.g. Wadensjö, 1992) and in liaison interpreting (e.g. Gentile et al., 1996), there have also been several volumes devoted to the rationale, the ethical ramifications, the practical hurdles and the logistics of interpreting in legal settings (e.g. Berk-Seligson, 1990; de Jongh, 1992; Corsellis, 1995; Edwards, 1995).

The latest in this growing collection, Interpreters and the Legal Process, takes this development a step further. To begin with, it goes beyond the courtroom, to include the entire gamut of legal processes (e.g. asylum-seeking, police interviews, probational functions, and prison procedures). Secondly, it deals with the needs of the deaf and hard-ofhearing, including a discussion of the alternative forms of communication available (sign languages, computer-assisted transcription, etc.) and a historical account of how deaf and hard-of-hearing people have been dealt with by the legal system. Finally, it is an example of interdisciplinary collaboration at its most effective: Joan Colin is a justice of the peace; Ruth Morris is a professional interpreter and an academic, whose PhD dealt with courtroom interpreting. The combination of legal and linguistic perspectives which the two authors bring to bear introduces the reader to the whys and wherefores of interpreting for the non-English speaker in English-speaking countries - from the legal and human rights standpoints - while also offering practical advice to the practitioners who must make it happen in the most equitable and professional way. The authors' clear aim is to ensure that a high standard of interpreting is provided to non-English speakers, limited-English speakers and deaf people, so that all those who come into contact with the legal system are on an equal footing.

While acceptance of the basic right to language equality is reflected in the letter of the law in many countries, those in charge of implementation - including legal practitioners - are often insufficiently aware of the issues which must be addressed. Chapter 1 : "Language, Communication, Interpreting and the Law", helps debunk the still-common myth of the interpreter as an impassive, transparent presence. Attention is drawn to the fact that an interpreter's use of language can never exactly parallel the message as delivered in the other language. Intra- and interlingual deliberations entailed in choosing language will not only affect the surface meaning but will also determine the extent to which the target-language "equivalent" corresponds in terms of connotation, register and other overtones. No formula can be offered which would cover every interpreting situation; ultimately, it is up to the interpreter to deal with the communication issues and the inherent dilemmas of intercultural and interlinguistic communication in settings which are often highly regimented as well as heavily charged.

The detailed review of "Interpreters and the Police" (Chapter 2) examines the actual implementation of Code C of the Police and Criminal Evidence Act 1984, which outlines

Meta, XLIII, 1, 1998 